\title{
The Role of p24 Immunohistochemistry to Identify HIV Lymphadenitis
}

\author{
Muhartono $^{1 \#}$, Indri Windarti ${ }^{1}$ \\ ${ }^{1}$ Department of Pathology, Faculty of Medicine, Lampung University \\ *Corresponding Author E-mail: dmuhartono@yahoo.com
}

\begin{abstract}
Introduction : That was a difficulty to diagnose the early stage of HIV while the symptoms was only enlargement of the lymph nodes, so that the pattern A of HIV lymphadenitis that presented on histopathological examination is expected to be a determinant of early-stage. Although the staining of p24 antibody has already be used to detect HIV infection in the tissue, but the positivity of p24 in pattern A HIV lymphadenitis has not been investigated.

Methods : This is a retrospective descriptive study. We collected 64 cases of non spesific lymphadenitis from the Anatomical Pathology archive, Cipto Mangunkusumo hospital and examined these cases by using the criteria of pattern A HIV lymphadenitis in the tissue specimen. Then we performed the staining of p24 antibody by immunohistochemistry.

Results : There were twelve by sixty four (12/64) cases of that have pattern A HIV lymphadenitis on microscopic evaluation. Only three cases was clinically noted as Acquired Immunodeficiency Syndrome (AIDS) by clinician, while 11 of 12 cases showed immunohistochemistry positive for p24 antibody.

Conclusion : Most of the patten A HIV lymphadenitis (11/12) showed the positive staining for p24 antibody. In patients who had received Anti Retro Viral (ARV) therapy, the staining of p24 antibody was negative. This study still needs more samples, the serologic data of the patient to be more reliable.
\end{abstract}

Keyword: HIV, pattern A HIV lymphadenitis, p24.

\section{Introduction}

Since the early $21^{\text {th }}$ century an increasing number of cases of Human Immunodificiency Virus (HIV) continues to be concerned. There are 33.4 million people living with Human Immunodeficiency Syndrome in 2008, 20\% higher than in 2000 and more than tripled compared to $1990 .{ }^{1}$ In the case of Acquired Immunodeficiency Syndrome (AIDS) in Indonesia in the period 10 years (1987-1997) that 
ISSN 25980580

increases slowly, in 2000 has increased very sharply. ${ }^{2}$ An increasing number of AIDS cases continue to occur, the number of cases in 2005 increased nearly doubled from 2004, and the first quarter of 2010 the number of reported AIDS cases increased 591 cumulative of AIDS cases so that the period 1987 to March 2010 counted to 20,564 with 3,936 deaths. ${ }^{2,3}$

Enlarged lymph nodes/lymphadenopathy is the most common symptom in patients with HIV infection, may occur as early manifestations of infection or can also be found at any stage of HIV infection. ${ }^{4-6}$ At least $25 \%$ of patients with AIDS have lymphadenopathy that can be found on physical examination. $^{7}$

The diagnosis of HIV infection is critical in deciding the chain of HIV transmission because the HIV infected patients can be a source of infection due to a very high viremia or due to the patient not knowing that he was infected by HIV so he did nothing to prevent transmission. However, clinically it's difficult to diagnose the early-stage HIV with only symptoms of enlarged lymph nodes. ${ }^{8}$ After years, the researchers have succeeded in classifying HIV lymphadenitis devided by 3 pattern (pattern A, B and C) on histopathological examination. ${ }^{9,10}$

In case that there is no data of serologic HIV infection, the Pattern A HIV lymphadenitis that found on histopathologic examination is expected to be a determinant of early-stage HIV infection. Although p24 antibody can already be used to detect HIV infection in the tissue, the positivity on pattern A HIV lymphadenitis of the tissue specimen has not been investigated. If there is high p24 positivity on pattern A HIV lymphadenitis, it will be able to represent HIV infection is in the early stage so that it can be used as a basic for more intensive management of breaking the chain of infection.

\section{Methods}

This study is a retrospective descriptive study. Material obtained from the histopathology slides archives of the Department of Anatomic Phatologic, Faculty of Medicine University of Indonesia/Cipto Mangunkusumo Hospital using topography codes C77 and H293 morphology according to ICD-O, then we obtained the registration number of patients. We conducted a reevaluation of the histopathologic slides with chronic lymphadenitis cases. Sixty four cases was found. The entire preparation performed histopathological reassessment using the criteria of pattern A HIV lymphadenitis: (a) Large lymphoid follicles and/or hyperplastic folicles, (b) reactive germinal center characterized by widespread apoptosis, phagocytosis of nucleur debris by tingible body macrophages, (c) No small lymphocytes (thinning of the mantle zone), (d) a group of small lymphocytes enter to and cause the damage of germinal center (foliculolysis), (e) interfolicular 
bleeding, (f) a cluster of monositoid cells around blood vessels and sinuses, (g) giant cells WarthinFinkeldey.

P24 immunohistochemical staining performed on slides that have pattern A HIV lymphadenitis. We did $4 \mu \mathrm{m}$ trimming of paraffin block and attached it to slides that have been coated with poly $\mathrm{L}$ lysine, incubated at $60^{\circ} \mathrm{C}$ for overnight. Then we did deparaffination, rehydrated and blocking of endogenous peroxidase reaction for 30 minutes. Between these two stages we did slides washing with tap water. Furthermore Antigen Retrieval Procedures performed in the microwave and then cooled in citrate buffer. Incubation of P24 primary antibody (clone Kal-1, Dako, Ely, UK) with a 1:40 dilution, carried out in a closed place at room temperature for 60 minutes, incubated with secondary antibody Biotinylated Goat Anti-Rabbit Ig (BAGR). Then given the chromogen diamino benzidine (DAB) $+30 \% \mathrm{H}_{2} \mathrm{O}_{2}$ in Tris $\mathrm{HCl} \mathrm{pH}$ 7.6. Among the three stages of washing with PBS $\mathrm{pH} 7.4$ and tap water and maintained not to dry. Counterstained performed with Mayer Hematoxylin. After that dehydration was performed and then covered with entellan.

\section{Results}

During 2 years $(2009$ - 2010) there was 64 cases recorded that had been diagnosed as chronic non-specific lymphadenitis. The number of cases of chronic non-specific lymphadenitis in 2009 and 2010 was 32 cases respectively. After reevaluation, of the 64 cases, there were 13 cases with pattern A HIV lymphadenitis (Table 1). Of 12 cases, only 3 cases (25\%) were noted as AIDS by clinician. There were 8 cases (67\%) male, and 4 cases (33\%) were female (Table 2). Three cases that have a feature of pattern A HIV lymphadenitis in this study were children (0-4 years old), 3 cases were in the 2 decades (11-20 years). Pattern A HIV lymphadenitis of the lymph nodes found in the neck area was 10 cases $(67 \%)$. 
Tabel 1. Characteristics of patients with chronic lymphadenitis and pattern A HIV lymphadenitis

\begin{tabular}{clcc}
\hline Characteristics of patients & $\begin{array}{c}\text { Chronic } \\
\text { lymphadenitis } \\
\mathbf{N}\end{array}$ & $\begin{array}{c}\text { Pattern A HIV } \\
\text { lymphadenitis } \\
\mathbf{N}\end{array}$ \\
\hline Sex & & \\
\hline$\bullet \quad$ Male & 28 & 9 \\
\hline$\bullet \quad$ Female & 23 & 3 \\
\hline Age & & 8 & 3 \\
\hline$\bullet \quad 0-10$ & 17 & 7 \\
\hline$\bullet \quad 11-20$ & 12 & 10 \\
\hline$\bullet \quad>20$ & & 3 \\
\hline Location & Colli & 31 & \\
\hline$\bullet$ & Inguinal & & \\
\hline
\end{tabular}

The most feature that found in the histopathology slides were large lymphoid follicles or hyperplastic folicles with reactive germinal center characterized by widespread apoptosis as shown in figure 1. The histopathology slides which showed 4 criteria of pattern A HIV lymphadenitis was 7 cases (42\%), 5 criteria was 2 cases (33\%), and 3 criteria was 1 case (8\%), and the slides which have 2 criteria was 2 cases (17\%). One case was excluded from the study because immunohistochemical staining cannot be done.

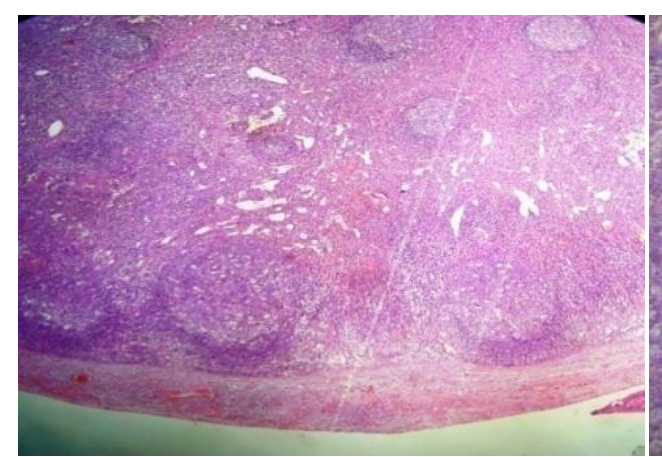

(A)

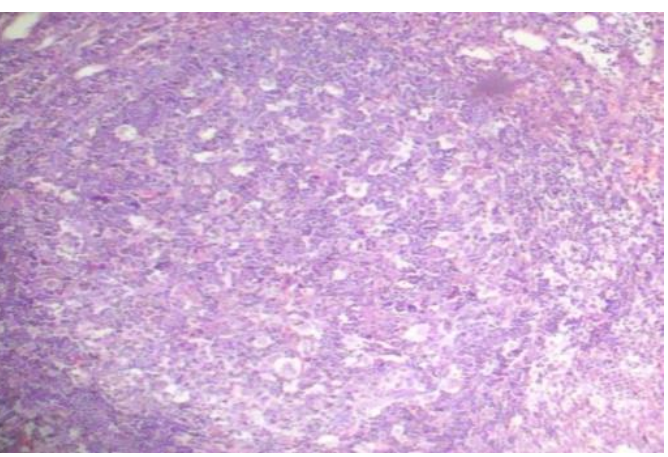

(B)

Figure 1. Hyperplastic folicle of the lymphnode $(A)$ and reactive germinal center $(B)$.

Of the twelve cases which have a feature of pattern A HIV lymphadenitis, as many as 11 cases showed positive for p24 antibody, and 1 case which negative for p24 was on antiretroviral therapy 
stated by clinician. Figure 2 showed the positivity of p24 antibody using immunohistochemical staining. The positivity stained the dendritic cells between the lymphocytes.

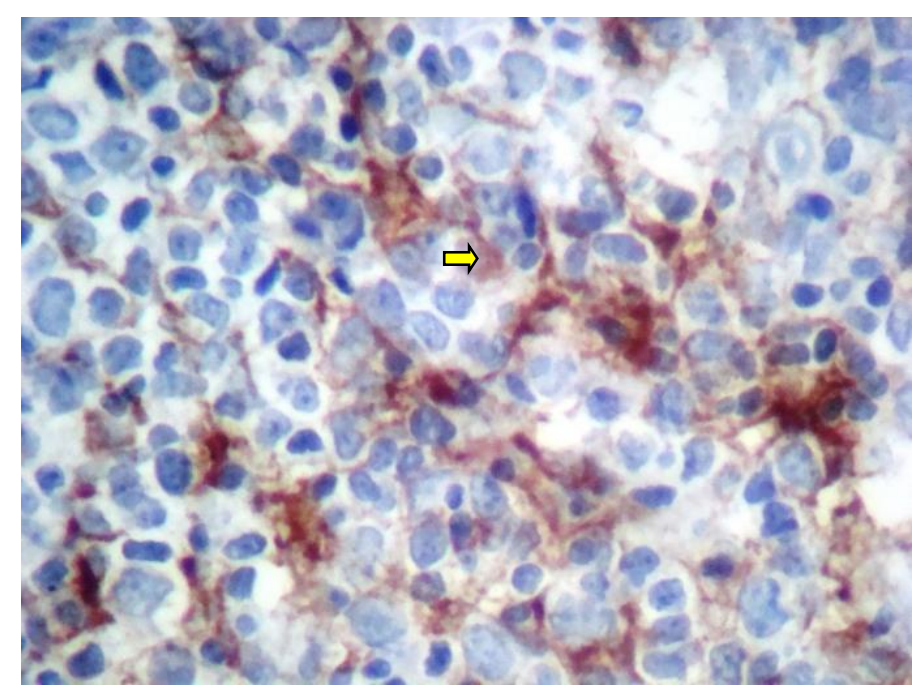

Figure 2. positivity of p24 antibody in dendritic cells

Tabel 2. Histopathology features using the criteria of Pattern A HIV lymphadenitis and $\mathbf{p} 24$ positivity

\begin{tabular}{|c|c|c|c|c|c|c|c|c|c|c|}
\hline \multirow[b]{2}{*}{ No. } & \multirow[b]{2}{*}{$\begin{array}{l}\text { Age } \\
\text { (years) } \\
\text { /gender }\end{array}$} & \multirow[b]{2}{*}{ Clinical description } & \multicolumn{7}{|c|}{ Criteria of pattern A HIV limfadenitis } & \multirow[b]{2}{*}{ p24 positivity } \\
\hline & & & 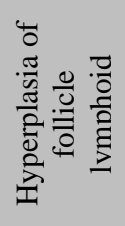 & 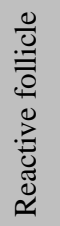 & $\begin{array}{l}\frac{\infty}{\infty} \\
\frac{2}{0} \\
\frac{0}{3} \\
.0 \\
0 \\
0\end{array}$ & 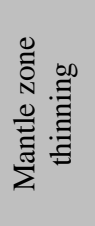 & 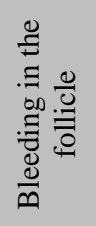 & 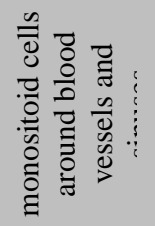 & 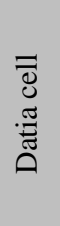 & \\
\hline 1. & $4 / \mathrm{M}$ & Multiple lymphadenopathy & $\sqrt{ }$ & $\sqrt{ }$ & $\sqrt{ }$ & $\sqrt{ }$ & - & - & - & Centrum \\
\hline 2. & $56 / \mathrm{M}$ & Sialolithiasis \& sialadenitis & $\sqrt{ }$ & - & $\sqrt{ }$ & $\sqrt{ }$ & - & - & - & Centrum \\
\hline 3. & $1 / \mathrm{M}$ & Abccess colli dextra \& & $\sqrt{ }$ & $\sqrt{ }$ & $\sqrt{ }$ & $\sqrt{ }$ & - & - & - & Centrum \\
\hline 4. & $2 / \mathrm{M}$ & lymphadenopathy colli & $\sqrt{ }$ & $\sqrt{ }$ & $\sqrt{ }$ & $\sqrt{ }$ & - & - & - & Paracortex \\
\hline 5. & $19 / \mathrm{M}$ & lymphadenopathy colli & $\sqrt{ }$ & - & - & $\sqrt{ }$ & - & - & - & Paracortex \\
\hline 6. & $14 / \mathrm{F}$ & lymphadenopathy colli & $\sqrt{ }$ & $\sqrt{ }$ & $\sqrt{ }$ & $\sqrt{ }$ & - & - & - & Centrum \\
\hline 7. & $47 / \mathrm{F}$ & lymphadenopathy & $\sqrt{ }$ & $\sqrt{ }$ & $\sqrt{ }$ & $\sqrt{ }$ & - & - & - & Centrum, sinus \\
\hline 8. & $13 / \mathrm{F}$ & lymphadenopathy colli & $\sqrt{ }$ & $\sqrt{ }$ & $\sqrt{ }$ & $\sqrt{ }$ & $\sqrt{ }$ & - & - & Centrum, sinus \\
\hline 9. & $37 / \mathrm{F}$ & lymphadenopathy multipel & $\sqrt{ }$ & $\sqrt{ }$ & $\sqrt{ }$ & $\sqrt{ }$ & $\sqrt{ }$ & - & - & Centrum \\
\hline 10 . & $27 \mathrm{M}$ & lymphadenopathy colli & $\sqrt{ }$ & $\sqrt{ }$ & $\sqrt{ }$ & $\sqrt{ }$ & - & - & - & Centrum \\
\hline 11. & $29 / \mathrm{M}$ & lymphadenopathy colli + & $\sqrt{ }$ & $\sqrt{ }$ & $\sqrt{ }$ & $\sqrt{ }$ & - & - & - & Centrum \\
\hline 12. & $25 / \mathrm{M}$ & lymphadenopathy colli + & $\sqrt{ }$ & - & $\sqrt{ }$ & - & - & - & - & Negative \\
\hline
\end{tabular}




\section{Discussion}

After an assessment of the pattern of HIV lymphadenitis and staining of p24 antibody. We found that $67 \%$ cases were male and 33\% were female (Table 3). Moonim et al research found $65 \%$ patient with AIDS were male. ${ }^{10}$ According to Rasmaliah ${ }^{11}$ sex ratio between men and woman is 10-15:1 because most of them are homosexuals, while in another country he obtained that sex ratio is 1: 1.11, while statistical data of HIV/AIDS cases in Indonesia were reported up to March 2010 found the number of AIDS patients is 15,168 men, unlike women, the 5,306 patients with a ratio of $3: 1 .^{3}$ In this study we didnot found the information of the homosexual status of the patients, so it can't be concluded whether the patient has a tendency to homosexual or heterosexual.

Of the 12 cases, only 3 cases were accompanied by a description of the AIDS. This is because most of the patients may be in the early phase or phases of latent HIV and have no symptoms other than enlarged lymph nodes, so that clinicians often do not suspect the possibility of HIV infection because of the limitations of serology in the latent phase in which the levels of CD4+ and examination of viral load didi not shown a significant decline. ${ }^{4}$

Three cases have a picture of HIV lymphadenitis A pattern found in this study were children (04 years). This is possible because in addition to HIV transmission can occur through sexual contact and parenteral, it may also happened that the mother-child transmission is the main cause of AIDS in children. ${ }^{4}$ Mother can transmit the infection through three channels: (1) in utero which spread through the placenta, (2) During delivery through the birth canal infection with the risk of transmission of 50\%, and (3) after birth through breast milk (14\%). During the intrapartum and peripartum transmission is more common in children in Amerika. ${ }^{4,7}$ Prevention of mother-child transmission can be done through early diagnosis of cases of HIV in pregnant women and treted them with antiretroviral (ARV) therapy. ${ }^{4}$

A pattern of HIV lymphadenitis of the lymph nodes in the neck area as many as 10 cases $(67 \%)^{4,12,13}$ In addition to the lymph nodes in the neck, HIV lymphadenitis can also occur in the inguinal and axilla. ${ }^{7}$ In this study we did not found HIV lymphadenitis of the inguinal and axilla, but there were 2 cases with multiple lymphadenopathy information with biopsy on lymph nodes in the neck without mentioning the presence of enlarged lymph nodes in other areas. The possibility of the presence of enlarged lymph nodes in the inguinal and axilla regions can't be ruled out because the information is often incomplete.

Four criteria predominantly found in this study are: enlarged lymphoid follicles and/or hyperplastic, reactive germinal center characterized by tingible body macrophages, extensive 
ISSN 25980580

apoptosis, phagocytosis core debris. Furthermore, small lymphocytes were also found but in a very little amount or even no that cause thinning of the mantle zone, and foliculolysis. $(14,15,16)^{14,16,17}$

Reactive germinal center characterized by widespread apoptosis, phagocytosis of debris and tingible body macrophages may be the result of a direct effect of cell killing by the virus that may occur due to colonization of HIV in lymph node architecture that is causing damage to the lymph nodes and progressive change of the lymph nodes. ${ }^{4}$ Direct cytopathic effects of replicating virus led to the death of infected cells. ${ }^{4,15}$

Fusion of infected cells and uninfected cells can cause formation of giant cell which is in this study was not found. This may occur because the giant cell formed by the fusion will be enlarged (balloning) and die within a few hours. ${ }^{4}$ Monositoid group of cells around blood vessels may cause by circulating monocytes infected with HIV. Monocytes in the peripheral cells associated with HIV-RNA viral load, and can be an indicator of abnormalities in the lymph nodes, but little is known about the quantitative distribution of HIV-containing monocytes in the lymph. ${ }^{16,17}$ Of the twelve cases which have a picture of pattern A HIV lymphadenitis, as many as 11 cases showed positive for p24, but 1 case with negative p24 antibody was state as AIDS on antiretroviral therapy. Of the 11 cases found to have positivity not only in germinal center but also showed positivity in the sinuses and paracortex of the lymph node. In the study conducted by Moonim et al, p24 positivity is not only found on dendritic cells in the follicle. ${ }^{10}$ The study found 22 cases $(60 \%)$ of p24 that characterizes other cells of lymphocytes in the follicle cells, lymphocytes in the mantle zone, small and large lymphocytes in paracortex, macrophages and giant cells. In all of these cases occurred in the p24 positivity in the cytoplasma. $^{18}$

In this study, p24 positivity can only be determined location. Positivity in the germinal center even varies in intensity from weak to strong staining. This may occur because of the latent phase of follicular dendritic cells which already began to malfunction or low viral load in the acute phase. A total of six cases $(50 \%)$ also showed positivity in paracortex, which may be the macrophage. The mechanism of viral entry into cells is through the T cell receptor CD4 and macrophages. Viral replication in lymph nodes may cause viremia and spread of the virus. Viremia is controlled by the host immune response so that the patients is on the latent phase. Macrophages were infected by HIV can't be lysed by T cells. ${ }^{4,18}$ 
ISSN 25980580

\section{Conclusion}

Most cases with pattern A HIV lymphadenitis showed a positive staining for p24 antibody. Highest positivity found in a germinal center. This study is a preliminary study that needs to be followed by increasing the number of samples and complete clinical data such as serology status, CD4 + , HIV and viral load phase to be more comprehensive.

\section{Acknowledgment}

Thank you to Dr. Endang S.R. Hardjolukito, MS., Sp.PA(K) on knowledge, patience and spare time to guide this retrospective study.

\section{References}

1. Joint United Nations Programme on HIV/AIDS (UNAIDS) and World Health Organization (WHO). AIDS epidemic update 2009. Switzerland: WHO Library Cataloguing in Publication Data; 2009.

2. Komisi Penanggulangan AIDS. Strategi nasional penanggulangan HIV dan AIDS 2007-2010. Jakarta: Komisi Penanggulangan AIDS; 2007.

3. Ditjen PPM \& PL Depkes RI. Statistik kasus HIV/AIDS di Indonesia dilapor sampai dengan Maret 2010. Jakarta: Ditjen PPM \& PL Depkes RI; 2010.

4. Mac Adam AJ, Sharpe AH. Infectious disease. In: Vinay K, Alice H, Arthur AB, editors. Pathology basis of disease.7th ed. Pennsylvania: Saunders Elsevier; 2005. p. 386-7.

5. Yogev R, Chadwick EG. Acquired immunodeficiency syndrome (human immunodeficiency syndrome). In: Behrman RE, Kliegman RM, Jenson HB, editors. Nelson textbook of pediatric.17th ed. Pensilvania: Saunders Elsevier; 2004. p. 1109-19.

6. Shobana A, Guha SK, Mitra K, Dasgupta A, Neogi DK, Hazra SC. Poeple living with HIV infection/AIDS-A study on lymph node FNAC and CD4 count. Indian J Med Microbiol 2002; 20(2): 99-101.

7. Klatt EC. Lymphnode pathology in AIDS. In: Klatt EC, editors. Pathology of AIDS. Savannah: Mercer University of Medicine; 2010. p.185-92.

8. Coco A. The cost-effectiveness of expanded testing for primary HIV infection AIDS. Ann Fam Med 2005; 3(5): 391-9.

9. Paiva DD, Morais JC, Pilotto J, Veloso V, Duarte F, Lenzi HL. Spectrum of morphologic changes of lymph nodes in HIV. Mem Inst Oswaldo Cruz 1996; 91(3): 371-9.

10. Moonim MT, Alarcon L, Freeman J, Mahadeva U, Walt J, Lucas S. Identifying HIV infection in diagnostic hystopathology tissue samples-the role of HIV1-p24 immunohystochemistry in indentifying clinically unsuspected HIV infection: 3-years analysis. Histopathol 2010; 56(4): 530-41.

11. Rasmaliah. Epidemiologi HIV/AIDS dan upaya penanggulangannya. Medan: USU digital library; 2001. 
12. Alos LC, Navarrete P, Morente V, Garcia P, Garrido M, Plana M et al. Immunoarchitecture of lymphoid tissue in HIV-infection during antiretroviral therapy correlates with viral persistence. Modern Pathol 2005; 18(1): 127-36.

13. Ioachim HL. Immunopathogenesis of Human Immunodeficiency Virus infection. Cancer Research 1990; 50(17): 612-7.

14. Kuster H, Opravil M, Ott P, Schlaepfer E, Fischer M, Gunthard HF et al. Treatment induced decline of Human Immunodeficiency Virus-1 p24 and HIV-1 RNA in lymphoid tissue of patients with early Human Immunodeficiency Virus-1 infection. Am J Pathol 2000; 156(6): 1973-87.

15. Alimonti JB, Ball TB, Fowke KR. Mechanisms of CD4+ T lymphocyte cell death in human immunodeficiency virus infection and AIDS. J Gen Virol 2003; 84(7): 1649-61.

16. Westhorpe CLV, Zhou J, Webster NL, Kalionis B, Lewin SR, Jaworowski A et al. Effects of HIV-1 infection in vitro on transendothelial migration by monocytes and monocyte-derived macrophages. J Leukoc Biol 2009; 85(6): 1027-35.

17. Jiang WI, Lederman MM, Salkowitz JR, Rodriguez B, Harding CV2, Sieg CF. Impaired monocyte maturation in response to $\mathrm{CpG}$ oligodeoxynucleotide is related to viral RNA levels in human immunodeficiency virus disease and is at least partially mediated by deficiencies in alpha/beta interferon responsiveness and production. J Virol 2005; 79(7): 4109-19.

18. Coleman $\mathrm{CM}, \mathrm{Wu} \mathrm{L}$. HIV interactions with monocytes and dendritic cells: viral latency and reservoirs. Retrovirology 2009; 6(51):1-12. 